\title{
CULTURAL GENESIS AND THE FINAL OF ZRUBNA/TIMBER-GRAVE CULTURE OF THE NORTH AZOV AREA (THE LATE BRONZE AGE)
}

\author{
VI A CHESLAV Z A B A V I - M A K S M B U LYK
}

\begin{abstract}
The article is concerned with the cultural genesis of Zrubna culture in the North Azov Area, its emergence in the area and the initial stage of development. The author provides historiographical overview of the problem and considers the main concepts of the genesis and the development of Zrubna culture in the region under research. The article also describes a number of ritual and inventory features characterizing the initial burial sites of Zrubna culture of the North Azov Area with Pokrovsk features. It was those sites that were recognized the earliest ones typical of the region's Zrubna culture following the times of the burial sites of Babino cultural circle. As far as culture and history, the emergence of Zrubna culture in the North Azov Area is associated with migration of Pokrovsk-type sites' bearers from the Woodland Grass of the Don Area through the basin of the Siverskyi Donets with active participation of the autochthonous Babino population. The article also considers issues concerned with determining the upper chronological limits of Zrubna culture on the territory of Left-Bank Ukraine and the North Azov Area, in particular the limits marking disappearance or transformation of Zrubna culture into new formations of the final stage of the late Bronze Age.
\end{abstract}

Keywords: Zrubna/Timber-Grave culture, late Bronze Age, North Azov Area, cultural genesis, ritual and inventory complex.

\section{INTRODUCTION}

The issues concerned with the emergence and the initial development stage of Zrubna/TimberGrave culture (hereinafter referred to as ZC) in the North Azov Area and in the basin of the Siverskyi Donets were addressed many times in works by R. Lytoynenko (1993; 1994a; 1995; 1999). In the researcher's view, there are no prominent sites of Pokrovsk type (Pokrovsk Zrubna culture hereinafter referred to as PZC) viewed as the transitionary and the earliest layer of $Z C$ formation. Here we can see a well-molded ZC, whose earliest sites have quite a few Pokrovsk elements. The North Azov Area is known to have quite a few burial sites with vague Pokrovsk features in the rite and in the inventory apparently dating back to the end of the early-the beginning of the developed stage of the Siverskyi Donets burial grounds. But it is those complexes that are the earliest ones for the Azov ZC following the times of burial sites of Babino cultural circle (Babino culture, a culture of multi-rolled ceramics and a culture of multi-elastic ceramics hereinafter referred to as BCC; Lytoynenko 1994a, 172).

The author pays special attention to the fact that the most expressive of those complexes comparable to Pokrovsk antiquities tend territorially towards the northeast: that was where the sites of Pokrovsk type came from. This again confirms the trend of gradual decrease in Pokrovsk impulse in the western direction, which was emphasized in literature many times (Lytoynenko 1995, 81; 1999, 21; Otroschenko 2013, 162; Sharafutdynova 1993, 89; 1995, 100). Analysis of Pokrovsk-type burial sites made it possible for the researcher to make a conclusion that those complexes do not embrace a short-term period alone. They embrace an appreciably longer period of time. In this respect, earlier burial sites are almost similar to classical Pokrovsk-type sites, whereas later ones, where most of the burial sites found here belong, are characterized by well-formed ZC burial traditions, some particular Pokrovsk features being preserved (Lytvynenko 1995, 79).

The problem of cultural genesis of $\mathrm{ZC}$ of the North Azov Area was addressed in works by V. Samar. Thus, being a peripheral culture in the North Azov Area, Pokrovsk culture (according to the author's terminology): "Carries features of the simultaneous BCC as well as those of Zrubna culture at its formation stage." (Samar 1998, 75). Within the Azov Highlands, the burial sites with 'Pokrovsk' and 'Pokrovsk multi-rolled' features outnumber the early Babino complexes. Late Babino complexes and burial sites of 'Pokrovsk' culture in the North Azov Area have common features, such as northern orientation and a little bit contorted positions of the dead as well as some forms and decorative compositions of ceramics and position of the arms at the time of burial. The researcher also emphasizes that the roll typical of 'Pokrovsk' culture is replaced by crude 


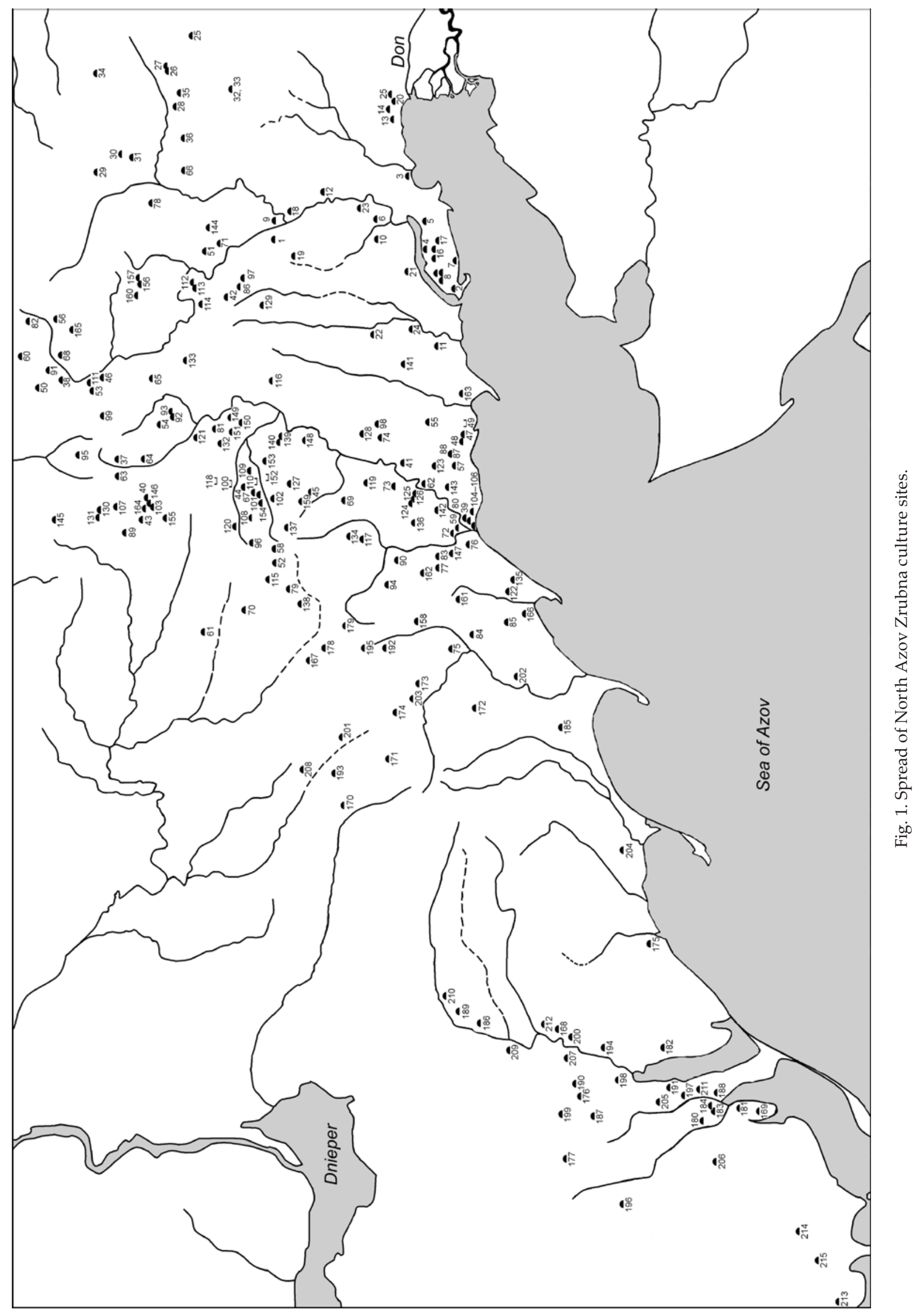


scratches as well as by drop-like and figure-made incisions on the crockery, the idea of embossed elements on ornaments and weapons being preserved. Here one can find new types of ornaments and weapons (Samar 1998, 82).

Tab. 1. Orientation of the dead to the northern sector on burial sites according to the horizons.

\begin{tabular}{|l|c|c|c|c|}
\cline { 2 - 5 } \multicolumn{1}{c|}{} & \multicolumn{2}{c|}{$\begin{array}{c}\text { North + North/ } \\
\text { North-East }\end{array}$} & \multicolumn{2}{c|}{$\begin{array}{c}\text { Total number of burial } \\
\text { sites according to the } \\
\text { horizons }\end{array}$} \\
\cline { 2 - 5 } & Absolute value & $\%$ & Absolute value & $\%$ \\
\hline Horizon I & 25 & 43,1 & 58 & 100 \\
Horizon II & 22 & 3,4 & 639 & 100 \\
Horizon III & 16 & 4,1 & 389 & 100 \\
\hline Total & 63 & 5,8 & 1086 & 100 \\
\hline
\end{tabular}

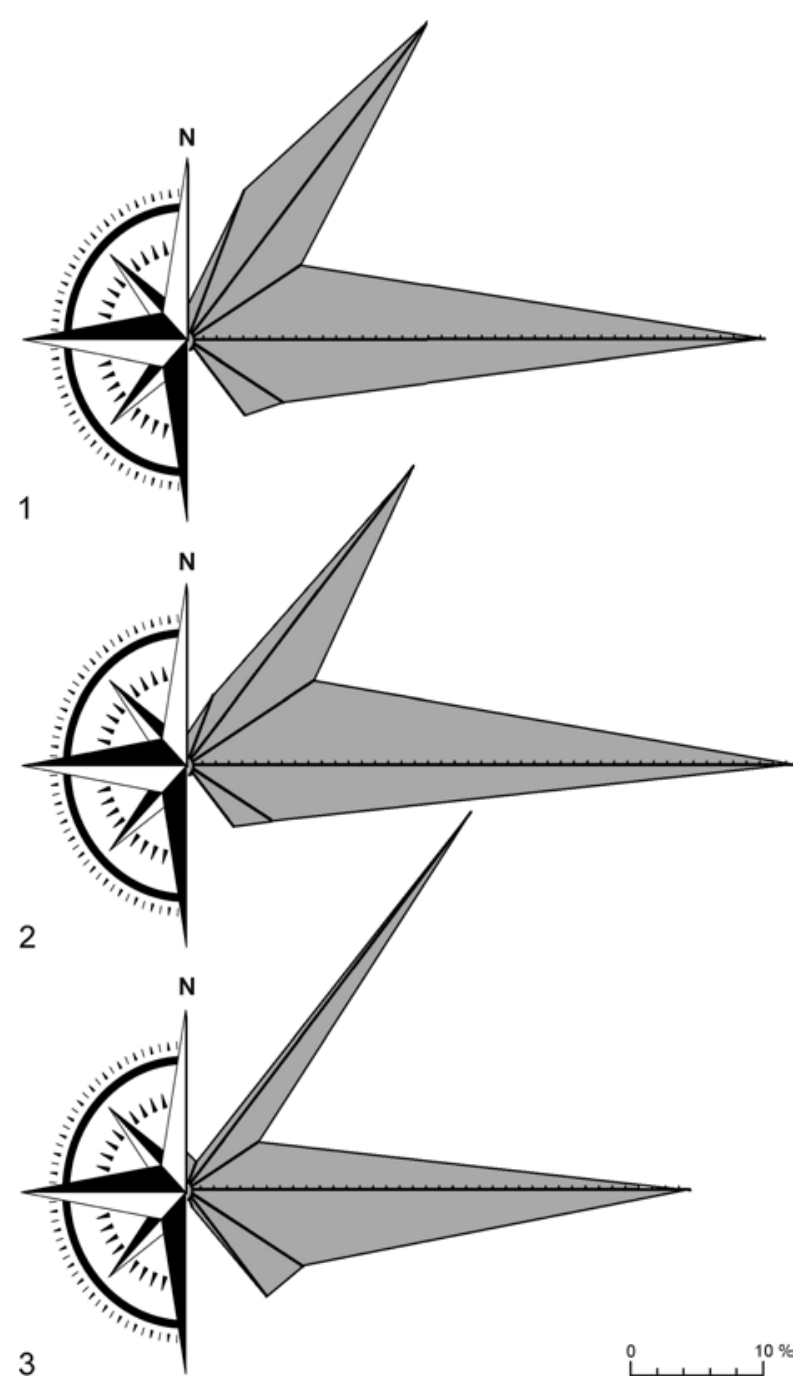

Fig. 2. Diagrams showing orientation of Zrubna culture burial sites: 1 - North Azov Area; 2 - Azov Area (lowlands and highlands); 3 - Donets Chain of Hills.
Existence of the so called transitional 'Pokrovsk timber-grave' burial sites is explained by E. Sharafutdynova by relatively smooth and gradual evolution of Pokrovsk-type sites into ZC, which complicates their cultural definition. The author recognizes ceramics as the main cultural feature or criterion for defining thereof (Pokrovsk details of any kind in a form or in an ornament), since other categories of products are found rather rarely on late Pokrovsk-type sites (Sharafutdynova 1995, 103).

In describing Pokrovsk-type complexes on the Siverskyi Donets, R. Lytvynenko also attached the decisive role to ceramics. Over all, in the researcher's view, ceramics appeared in late Pokrovsk complexes. This ceramics is distinguished by a kind of amorphousness and resembles the crockery of the developed Zrubna culture in form and ornament, some characteristic features of Pokrovsk crockery still being preserved (Lytoynenko 1995, 73, 74).

\section{CULTURAL GENESIS \\ OF NORTH AZOV ZRUBNA CULTURE}

Taking into account the predecessors' experience (Lytoynenko 1994a; 1999) and on the basis of the developed criteria of Pokrovsk-type sites (Pokrovsk Zrubna culture or PZC) of the neighboring regions (the Siverskyi Donets and the Lower Don Area), the author tried to determine and to characterize the oldest ZC sites of the North Azov Area (Fig. 1). The work done showed that the earliest Azov ZC burial sites are also characterized by certain Pokrovsk features, such as burials in ground pits concealed under timber, more rarely under stone; left-side slight or medium contorted position of the body; orientation to the northern sector; as far as the ceramic complex, there is a number of crockery items distinguished by a series of archaic features derived from Pokrovsk traditions; bronze knives with slightly expressed extensions marking a rhombic intersection (cf.: Lytoynenko 1994a; 1999).

On the other hand, one can say that the rite and inventory complex of the earliest Azov ZC burial sites is also equally characterized by a certain number of features reflecting the autochthonous Babino tradition (the position of arms, the orientation of the dead, the relics of the past in the material complex, etc.).

Bearing it in mind that orientations to the northern sector are traditionally associated with PZC (Tab. 1), we have drawn up separate histograms for the North Azov Area and for the Donets Chain of Hills (Fig. 2). The results obtained have reflected 
Tab. 2. Positions of the dead's arms in North Azov Zrubna culture burial sites.

\begin{tabular}{|c|c|c|c|c|c|c|}
\hline \multirow{2}{*}{ Position } & 1 & II & III & IV & v & \multirow{2}{*}{ Tota } \\
\hline & W & 니 & $\left.\right|^{\lrcorner}$ & LV & LL & \\
\hline Quantity & 478 & 11 & 49 & 77 & 9 & 632 \\
\hline Ratio (\%) & 75,6 & 1,7 & 7,9 & 12,2 & 1,4 & 100 \\
\hline
\end{tabular}

quantitative as well as qualitative distinctions between the burial sites. The share of northern deflections in the both regions appeared to be approximately the same, the eastern sector a little bit prevailing in the orientation of the Azov burial sites. Taking into consideration the fact that the late layer of the Dnieper-Don Babino culture sites (hereinafter referred to as DDBC) is characterized by orientation to the eastern sector and by the left-side position of the dead (Lytoynenko 2009a, 72) - this trend does not seem to be accidental. Thus, timber-grave antiquities of the North Azov Area occupy a kind of intermediary position between the districts with prevailing northern and eastern deflections in orientation of the dead.

Comparison of the two sub-districts of the North Azov Area (the Donets Chain of Hills and the Azov Area) did not reveal any striking quantitative or qualitative distinctions between them in terms of 'the posture of arms' (Tab. 2). The only distinction, such as the sixth position $(L\lrcorner)$ was found exceptionally on burial sites researched in the Azov lowlands and highlands. Such a position of arms on the area under research was typical of Babino burial sites of the early DDBC chronological horizon (Lytvynenko 2009a, 73, tab. $2 ; 4)$. It is noteworthy that joint cartography of the aforementioned burial sites and that of burial sites with Pokrovsk features has shown some differences in the areas of expansion thereof. Over all, one can observe closeness of Pokrovsk indices to the Lower Dnieper and the Donets ones, where the percentage of deflections from the normal position equals $30 \%$ i $31 \%$ respectively (Lytoynenko 1994a, 197; Otroschenko 1981, 114).

Cartography of Azov BCC burial mounds once made it possible to reveal an interesting situation. In spite of a great number of researched burial sites, BCC burial sites are fully unavailable in the coastal area of the Azov Sea spreading for about $30 \mathrm{~km}$. Differentiated cartography of various BCC burials revealed their absolute absence in the basins of the Yelanchyk and the Kalmius Rivers except for the upper current. Researchers reveal a similar situation on settlement sites. Thus, appearance of sites of the late early-the early developed ZC stages in the Azov Area known due to the materials of burial mounds is explained by the presence of 'a lacuna' that was formed (Sanzharov 1993, 24, 25).

According to R. Lytvynenko, migration of 'Abasheve/Pokrovsk' tribes to the Lower Don and to the Siverskyi Donets Area predetermined a considerable outflow of Babino population from the neighboring Azov/Donets Region to the west, to the Upper Dnieper Area, where a great number of related sites is observed in that period. The reality of Pokrovsk threat to the Upper Dnieper population is evidenced by discovery of an undercut grave of the late stage of the Dnieper-Prut Babino culture (hereinafter referred to as DPBC) in the Syvash Area, where the dead had been killed by an arrow (Lytoynenko 2009a, 72, 73; Otroschenko 2001, 96, fig. 17: 4-6). Thus, the author came to the conclusion that 'Pokrovsk expansion' to the west had caused a process that eventually led to BCC's removal from the historical arena and to creation of the late Bronze Age cultures on the basis thereof' (Lytvynenko 1995, 73).

On the basis of the latest remark, it will be interesting to emphasize that among Pokrovsk timber-grave complexes there is a burial site made in a burial structure in the form of an undercut grave. One can assume that this peculiarity of the burial structure also reflects the autochthonous Babino tradition (DPBC). Comparison of DPBC and DDBC in terms of 'the type of the burial structure' made it possible for R. Lytvynenko to reveal essential distinctions between them at the level of the forms and the proportions of grave-pit structures: rectangular structures of medium-size and short proportions are typical of DDBC, whereas oval and sub-rectangular pits of extended and medium-size proportions are typical of DPBC. At the same time, not less demonstrative for the latter is the structure in the form of an undercut grave that occurred a little bit less than in a half of the findings $(45,5 \%)$, whereas as for DDBC, it is an exception to the rule (2,5\%; Lytvynenko 2009b, 147). The undercut type of a burial structure is considered by the author as a criterion for differentiation of the late DDBC and DPBC complexes and a kind of a visiting card for burial sites of the Dnieper-Dniester variant of DPBC (Lytoynenko 2014, 29).

It is emphasized that 'the bulk of the Left-Bank Ukraine's territory' and the Azov Area in particular 
was part of the DDBC area. However, sites of the Dnieper-Dniester steppe variant of DPBC leaning toward the Upper-Dnieper Area are also known on that territory. Over all, the areal of that local variant described on the basis of cartography of diagnostic mound burials is limited, in the east by the LeftBank Dnieper Upper Rapids and by the DnieperMolochan Interfluve. To the east of the aforementioned boundaries, in the Upper Azov Area and in the adjacent Siverskyi Donets right-bank areas, the number of DPBC complexes is swiftly decreasing (Lytoynenko 2014, 28).

Taking into consideration a little bit later emergence of ZC in the North Azov Area compared with the Siverskyi Donets Area (Lytoynenko 2009b, 19), where the stratigraphic situation made it possible to assume the Pokrovsk-type sites and the late Babino culture sites being synchronous, R. Lytvynenko failed to definitely synchronize the aforementioned horizons in the region under research (Lytoynenko 1999, 21). To some extent, the time of ZC emergence in the North Azov Area can be made clear if we address the materials of the settlement sites.

In terms of understanding the process of $\mathrm{ZC}$ emergence in the region under research, a special significance must be attached to household sites researched in the Azov Area. For the first time ever the question of the possibility of contacts between the 'early timber-grave population' and the 'multi-rolled population' described in the sources concerned with Azov settlements was aroused by O. Shaposhnikova who in the mid-1960s carried out research of the multi-layer settlement of Razdolne located in the mean flow of the Kalmius River. The researcher determined the materials of the settlement's fourth horizon as early timber-grave ones. Joint range of ceramics of 'early timber-grave' and 'multi-rolled' traditions was found there. The author viewed the use of stone in building houses as influence of the local tradition. Thus, O. Shaposhnikova assumed that: "Zrubna culture was formed in the North Azov Area on the basis of multi-rolled culture and the eastern component." (Shaposhnikova 1970, 147-150).

A while later, on the basis of materials of Donets settlements, T. Shapovalov made a conclusion that influenced by 'Abasheve' (Pokrovsk) population and at a certain stage, the local 'multi-rolled' ethnos acquired a 'multi-rolled/Abasheve' appearance. This is evidenced not only by joint range of ceramics in a number of settlements. This is also evidenced by a certain amount of syncretic ceramics that unites 'multi-rolled' and 'Abasheve' features (Shapovalov 1979, 71, 72). In the 1980s-1990s V. Gorbov and A. Usachuk carried out large-scale stationary research of timber-grave settlements in the Azov Lowlands. In the settlement of Bezimenne, a complex characterized by Pokrovsk features was discovered, which made it possible for the authors to date it back to the first horizon of the North-East Azov settlements (Gorbov 1996). However, no Babino component was found there. This made it possible to assume that at the late stage of their development, the bearers of Babino culture left the drought-ridden Azov Lowlands but simultaneously kept living on the Highlands with a milder climate (Gorbov 2000, 55; 2001, 156; Lytoynenko 1994b, 29).

Addressing the materials of the excavation of the 1960s made by O. G. Shaposhnikova and having carried out their own research in the settlement of Razdolne, V. Gorbov and A. Usachuk managed to confirm O. Shaposhnikova's assumption of the possibility of contacts between the 'early timbergrave' and the 'multi-rolled' population. Overall, peculiarities of the settlement's ceramic complex made it possible for the authors of the excavation to compare it to the group of burial sites with 'vaguelooking' Pokrovsk features found in the North-East Azov Area. Besides, in evaluating the possibility of intercultural contacts, special attention was paid to syncretic ceramics reflecting Babino and Pokrovsk ceramic traditions (Gorbov 2001a, 181; Lytoynenko 1999, 19). However, unlike O. Shaposhnikova, V. Gorbov and A. Usachuk explain the emergence of stationery dwellings with stone-lined walls in 'multi-rolled' settlements by influence of new 'early timber-grave' population (Gorbov 2001a, 194). They explain the use of stone in building dwellings of the 'early timber-grave/multi-rolled' horizon by the eastern tradition (Gorbov 1997), whereas the very complex of Razdolne is a part of the first horizon of the North-East Azov settlements (Gorbov 1996). On the whole, in accordance with the theory of two lines in ZC development presented by V. V. Otroschenko, the 'early timber-grave/multi-rolled' horizon of Razdolne is viewed by the authors in the context of formation of Berezhnovka-Maevka Zrubna culture (here in after referred to as BMZC) on the basis of BCC sites and under the influence of an impulse given by Pokrovsk Zrubna culture (Gorbov 2001a, 194; Otroschenko 2001, 83).

Thus, as compared to the Upper Dnieper Area, materials concerned with Azov settlements evidence early penetration of the eastern population into the region. Peculiarities of building houses and the ceramic complex in the settlement of Razdolne made it possible for the authors of the excavation to date them back to 'the late Pokrovsk-the early timber-grave time', whereas the chronological markers and analysis of the ceramics made it possible for them to synchronize it with late Babino culture 
(Gorbov 2001b, 220). As early as at the very early stage, $\mathrm{ZC}$ bearers were exploring the Azov steppes: in the Azov Lowlands, they occupied practically empty lands, and in the Highlands, they were making contact with BCC bearers.

In this respect, attempts made by researchers to define the most optimal ways used by PZC population to penetrate the Azov steppes on the basis of materials of archeology and paleography look rather logical. Thus, V. Otroschenko assumed that in the late Bronze Age exchange and migration, in particular migration of PZC early timber-grave tribes between the Don and the Siverskyi Donets were made in two directions. The first direction is defined as the way that passed from the Don along the River Bila and along it to the River Aidar. The other direction is from the Don along the River Tykha Sosna to the River of Valui and the River Oskil (Otroschenko 1995, 18, 19).

V. Romashko explains migration of ZC tribes to the west in the late timber-grave times by directions extending the aforementioned ways. The first direction connected the Lower Donets Area and the North-East Azov Area with the steppe area of LeftBank Ukraine. However, the researcher emphasizes some difficulties in defining some certain geographical pegs of the migration ways, taking into consideration the wide range of lowland areas on that territories fit for migration and absence of serious waterway obstacles. According to V. Romashko, one of those ways could pass along the River Vovcha. That way connected the Azov Area with the basin of the River Samara, which explains proximity of the ceramic complexes of the lower horizon of settlements of Boguslav archeological area and those of Obitochna-12. Another way passed along the northern coast of the Azov Sea towards the passage through the Bug-Dnieper Firth (Romashko 2013, 221). According to some researchers, in the early Iron Age, that way was a part of the mainland's main road connecting the southern regions of the North Black Sea Area with the Upper Volga and the Upper Urals (Kopylov 1994, 91; Romashko 2013, 221). Another direction presupposes the Bronze Age ways that passed along the interfluve of the rivers Samara and Oril connecting the basin of the Siverskyi Donets with the Lower Dnieper Area (Kovaleva 1981, 3; Romashko 2013, 221).

According to E. Sharafutdynova: "The chronological position of Pokrousk-type sites (hereinafter referred to as PTS) is definitely squeezed out. They follow the sites of the closing period of the Mid Bronze Age and precede the timber-grave sites. The Middle-Don Catacomb culture and the cultural sites of multi-rolled culture (hereinafter referred to as MRC) were replaced by Pokrovsk type." Such a sequence is confirmed by some instances of direct stratigraphy found on the Siverskyi Donets and on the Lower Don. Here the author emphasizes: „A certain inter-impact of the late multi-rolled culture and PTS that were squeezing it; that was going on at the juncture of the both cultural groups and was caused by their pre-border location as a result of the change and by the former (MRC) squeezing the latter (PTS)." (Sharafutdynova 1995, 103, 104). In their turn, numerous stratigraphic observations made it possible for V. Otroschenko to make a conclusion that there were physical contacts between BCC and PZC bearers. The local population was apparently inferior to the newcomers. Then the author made a conclusion that: „Influenced by Pokrovsk population, MRC descendants changed their burial rite; they did not take the newcomers' mechanical rites. Being the ethnic minority, the latter switched to the BMZC rite and finally dissolved in the local environment." (Otroschenko 2001, 152).

According to R. Lytvynenko, the following situation is observed in the aforementioned period in the North Azov and in the Upper Dnieper Areas. There are no PZC relics in the region. Therefore, there is a trend of Babino complexes being followed by BMZC complexes in the stratigraphy of the burial mounds (Lytvynenko 1999, 19-21). Taking into account the chronological priority of PZC over BMZC, the reliable stratigraphy of the burial sites and the settlements as well as the typology of the findings, the author made a conclusion of a certain time lag in the process of replacement of Babino culture by Zrubna culture in the Dnieper/ Donets Region compared with the Don/Donets Region. According to R. Lytvynenko, the overall consequence of cultural changes at the end of the Mid-the beginning of the Late Bronze Age in the region under research looks as follows: the late Catacomb culture (primarily Dnieper/Azov culture/Ingul, less Bakhmut culture) $\rightarrow$ Babino culture (DDBC III + DPBC) $\rightarrow$ Zrubna culture (BMZC; Lytoynenko 2009a, 19).

The stratigraphic columns of the burial mounds located in the Upper Dnieper Area made it possible for V. Otroschenko to view the burial sites in the context of gradual change of archeological cultures: DDBC - PZC - BMZC, recognizing the fact of a certain synchronization of relatively late PZC burial sites with early BMZC burial sites. These cultural horizons reflect the consequence of the processes of the transitional period in the epoch of the late Bronze Age. In particular, one can observe the process of transformation of DDBC into BMZC with PZC participation. In the researcher's view, it is the presence of explicit Pokrovsk elements at the initial stage of the late Bronze Age that is very important. However, judging by the available materials, Pok- 
rovsk influence is obvious only at the final stage of DDBC (Otroschenko 2013, 164).

In the researcher's view, some peculiarities of the rites and the inventory in the burial mounds of the Upper Dnieper Area do not very much contradict an earlier date of BMZC burial sites and make it possible to speak about its bearers' participation in BMZC formation on the territory of the Left-Bank Dnieper Area. At the same time, these materials make it possible to clearly determine the boundaries of particular Pokrovsk manifestations' penetration to the west. V. Otroschenko explains distinctness of the existing picture of cultural traditions' mutual penetration by a complicated process of transformation of DDBC into BMZC on the territory of the Left-Bank Dnieper Area. The role of the catalyst herein was played by small groups of PZC bearers. Thus, in the Lower Dnieper Area and in the Upper Dnieper Area there was an overlapping of Pokrovsk features onto the late layer of BCC sites rather than a consequent change of cultures (DDBC - PZC - BMZC; Otroschenko 2013, 165). According to V. Otroschenko, Babino substrate is viewed as the basic one in the formation of BMZC from the Dnieper to the Volga. Another important consitutent of BMZC formation is the PZC population that came to the steppe at the first stage of its development. Here it is emphasized that BMZC was formed exactly in the zone of Pokrovsk penetrations and influences (Otroschenko 2001, 155).

All this is extremely important in terms of understanding the cultural and the migration processes as well as the historical fates of the North Azov ZC bearers of the late Bronze Age. However, taking into account Pokrovsk component in the Upper Dnieper Area and V. V. Otroschenko's understanding of the process of BMZC formation in the Left-Bank Dnieper Area facilitated by the local DDBC and by the eastern Pokrovsk component, we deem it expedient to emphasize the distinction in the 'mechanisms' of ZC cultural genesis on the Donets, in the Azov Area and in the Upper-Dnieper Area. Taking into consideration the trend of gradual decline in Pokrovsk impulse in the western direction (Lytvynenko 1995, 81; 1999, 21; Sharafutdynova 1993, 89; 1995, 100) and the fact that PZC relics are unavailable in the North Azov Aera and in the Upper Dnieper Area in the period under description, the stratigraphy of the burial mounds reveals a trend of BCC burials being followed by early BMZC complexes (Lytoynenko 1999, 19-21). Here one speak about a certain lag time in the process of replacement of Babino culture by Zrubna culture in the Dieper/Donets Region compared with the Don/Donets Region.

\section{FINAL OF THE NORTH AZOV ZRUBNA CULTURE}

Researchers also traditionally paid attention to issues concerned with defining the upper chronological limits of ZC on the territory of Left-Bank Ukraine and the North Azov Area, in particular issued concerned with defining the limits marking disappearance or transformation of ZC into new cultural formations of the final period of the late Bronze Age. Due to overall progress in knowledge of the late Bronze Age in Eastern Europe as well as due to permanent restocking of sources, understanding of a definite content of late Zrubna and post-Zrubna tribes was permanently changing. Profound historiography and analysis of various viewpoints of the problem were presented in V. Romashko's monographic research concerned with the final stage of the late Bronze Age in Left-Bank Ukraine. (Romashko 2013).

The peculiarity of the variants in solving the problem of the chronology and the cultural constituent of the final stages of the timber-grave society's existence lies in the fact that most of them is primarily based on the stratigraphy of the burial sites. The assumption of the end of ZC existence in the $13^{\text {th }}-12^{\text {th }}$ c. B.C. is gradually starting to dominate historiography (Berezanskaya 1982, 39, 40; Cherednichenko 1986, 44-82; Kovaleva 1981, 16-32; Lytoynenko 1994a, 168; 1999, 4-23; Otroschenko 2001, 160-162). The most justifiable modern approach to solving the problems of the origin, the development and the disappearance of the Zrubna culture society's cultures based on the principles of 'short' concept is proposed by V. Otroschenko. The concept is developed in the context of periodization of the cultures of Eastern Europe's mid- and late Bronze Age, where the issues of formation and the chronology of post-Zrubna cultures are highlighted in particular. (Otroschenko 2001; 2002; 2003).

According to V. Otroschenko, at the final stage of BMSC development, there was a deviation to the traditional burial rite, which inevitably led to the loss of cultural identity and, as far as archeology, it led to disappearance of ZC (Otroschenko 2001, 162). The author gradually proves that in the epoch of the late Bronze Age there was not a single burial site with BMZC features; thus - there was no culture at all. The steppe population was rapidly decreasing, though did not disappear. Life was going on in some particular settlements but in another cultural environment and at a different time (Otroschenko 2002, 22).

Thus, on the basis of the methodological principle that the most important feature of an archeological culture is a more or less standardized burial rite 
that remained unchanged with the time, the Azov burial sites of the final stage of the late Bronze Age represent another culture, since many of them demonstrate ritual features not typical of ZC. This problem is thoroughly researched by V. Potapov on the basis of the Lower Don materials and O. Probiiholova on the basis of the materials of the lower reach of the Siverskyi Donets and the Donets Chain of Hills (Potapov 2010a; Probyiholova 2012; 2017, 114-152). The late stratigraphic horizons of Azov settlements viewed by researchers as late ZC can be understood as 'post-Zrubna' ones; with disappearance of the Zrubna mound rite in the North Azov Area, ZC itself disappeared as well.

Influenced by V. Otroschenko's ideas, V. A. Romashko also gradually comes to the conclusion that in the epoch of the late Bronze Age the settlements still existed in the North Azov Area but in the framework of Boguslav/Bilozirsk culture (BCC) given to them (Romashko 2013, 28). Formation of $\mathrm{BCC}$ is going on in the $13^{\text {th }}$ c. B.C. Anyway, according to V. Romashko, during the last decades of that century there were sites of the new culture distinct from sites of the second BMZC period by explicit ceramic series of innovational appearance. Besides, the author views BMZC as the genetic background to the new cultural formation (Romashko 2013, 212).

In V. Otroschenko's view, the opportunity of handling closed complexes capable of providing for greater reliability of conclusions is given by the burial sites themselves (Otroschenko 2001, 161). As far the sites of the Left-Bank Dnieper and the Azov Area, some successful steps in defining burial sites of ZC final stage were made by researchers as far back as in the 1980s (Gavrilyuk 1982; Otroschenko/Shevchenko 1987). An important role in this development is played by research carried out by E. Sharafutdynova, who defined a number of late burial sites on the basis of the materials concerned with the Lower Don and the Steppe Kuban Area (Sharafutdynova 1991).

In the mid-1990s, on the basis of stratigraphic data, Yu. Polidovich and V. Tsymidanov made an attempt to date the timber-grave settlements of the upper stratigraphic horizon with a burial rite and a ceramic complex typical of BMZC to the times of Bilozirsk culture (the $12^{\text {th }}-10^{\text {th }}$ c. B.C.). The authors synchronized the late burial sites of the second BMZC period with the complexes of Bilozirsk culture (Polidovich/Tsimidanov 1994, 44-46). However, no crockery of the sort together or artifacts typical of Bilozirsk culture were found on any of the described burial sites. Later, V. Potapov outlined the settlements of the $12^{\text {th }}-10^{\text {th }}$ c. B.C. located in the Upper Don Area and in North-East Azov Area as a separate post-Zrubna chronological horizon
(Potapov 1998, 61-63). Later, as a result of detailed analysis, V. Potapov comes to the general conclusion in his dissertation 'Sites of the Lower Don late Bronze Age' that those sites belong to a separate Otradne culture (OC), thus summing up his longterm research. Analysis carried out by V. Potapov made it possible to define two ritual groups. As far as quantity, the first group prevails. This group is primarily characterized by orientation of the dead with their heads to the western sector, mediumcontorted positions of the dead on the right or on the left side, the latter position being appreciably prevalent. The other group is composed of burial sites with southern, south-western and western orientation of the dead (Potapov 2010b, 14-19). However, even after that, this theme has not lost its vitality in the context of discussion of the upper chronological limit of ZC. The discussion goes on the pages of Donetsk Archeological Compilation.

In their article, V. Podobed, A. Usachuk and $\mathrm{V}$. Tsymidanov present a new argumentation in favor of the upper dates of $\mathrm{ZC}$, considering 'late bronze' burial sites as the last burial sites of the timber-grave society. As a result of the research, the authors corrected the list of burial sites of the late Bronze Age by including new complexes from the territory of Left-Bank Ukraine, the Don Area, the Pre-Caucasian Area and the Lower Volga Area. The authors reviewed the status of the two ritual groups defined by V. Potapov (Otrande culture). With reference to orientation and position of the dead, they suggested distinguishing between four groups. Having analyzed those ritual groups, the authors united them into two blocks interpreted as diverse-culture ones. The researchers refer to burial sites of the first block as ZC, whereas complexes of the other block are supposed to retain the status of a separate 'Otradne' culture. Moreover, this culture becomes deprived of the status of an autochthonous one, and its origin is associated with migration of the eastern population. In the authors' view, interaction of various groups, one of them being the bearers of the 'late bronze' culture, was most likely to give birth to the ritual strictness in orientation and in positions of the dead demonstrated by the burials of the late Bronze Age found to the east of the Dnieper (Podobed/Usachuk/Tsimidanov 2012, 194-245).

According to Ia. Gershkovich, of course, prior to the beginning of the 'Bilozirsk period' in East Ukraine, groups of ceramics of the western (late Sabotynivka), the eastern and the north-eastern origin appeared in the settlements. The author presents them as multi-component ones and comparable to diverse-culture ceramic complexes. As far as the burial sites, migration transformation 
could affect the burial rite as well; the local burial traditions could be adopted, especially if the process of infiltration was going on not within short periods but within longer periods (Gershkovich 1998, 75, 76). In the North Azov Area, ceramics that reflects contacts with western cultures was found many times on settlement complexes as well (Gorbov 1995; 1996).

A little bit later, V. Podobed, A. Usachuk and V. Tsymidanov confirmed their commitment to the hypothesis developed by V. Gorbov that ZC still existed on the territory of the North-East Azov Area in the $12^{\text {th }}-10^{\text {th }}$ c. B.C. At the same time, the researchers were rather skeptical about the assumption of the cultural change in the Azov Area in the $12^{\text {th }}$ c. B.C. The authors suggested considering the problem of ritual strictness of the Azov burial sites belonging to the late Bronze Age from the viewpoint of cyclical theories. On the basis of the aforementioned, the authors deem it correct to use the term 'late bronze' ones when speaking about the burials of the late Bronze Age. They also suggest calling Chornohorivka sites (on the left bank of the Siverskyi Donets-Bondarykhine sites) 'post-Zrubna' ones (Podobed 2014, 94, 101).

V. Otroschenko also aroused the problem of defining burial complexes of the late Bronze Age in Left-Bank Ukraine (to the east of the River Molochna) and the problem of contacts between the populations of Otradne and Bilozirsk cultures in the context of the burial rite (Otroschenko 2012). A little bit later, coming back to the aforementioned discussion and having compared the materials concerned with the burial sites of the first and the second group once again, V. Potapov determined the features uniting them: the preeminently input character of the burial sites; combination of positions on the left and on the right sides, the left side being preeminently dominant; the same positions of the arms; available side meat food; available crockery in the burial sites of the both groups and its location in front of the dead's face in most cases. In spite of some particular distinctions between the aforementioned groups, localization of the both rite groups within one areal and the specificity of the ceramics made it possible for V. Potapov to assume that all those phenomena are within one Otradne culture. The author came to the conclusion that the burial sites of the late Bronze Age located in Ukraine and the burial sites of the first ritual group of Otradne culture are undoubtedly similar phenomena, though diverse-cultural. Following V. Otroschenko, Ia. Gershkovich and V. Romashko, V. Potapov is prone to refer to the East-Ukrainian burial sites of the late Bronze Age as those belonging to the post-Zrubna group (Potapov 2013, 240-254).
In our turn, we express our support for the idea of V.Potapov's accentuating the epoch of the late Bronze Age genetically connected with BMZC and the synchronous Bilozirsk epoch. Here we are emphasizing again that the Azov burial sites of the final stage of the Bronze Age represent another culture, since they demonstrate the ritual features not typical of ZC.

After disappearance of PZC, BMZC population was developing for two centuries more, which made it possible for V. Otroschenko to assume that theoretically it could absorb a certain amount of bearers of the vanished PZC, though there is no impartial evidence to this process. In the author's view, completion of BMZC development is caused by the process of splitting the Proto-Iranian branch of the timber-grave society the population of this culture belongs to. This process is also defined by linguists as that dating back to the late $2^{\text {nd }}$ millennium B.C. According to V. Otroschenko, in the epoch of abrupt change of the climate in the steppe zone of Eastern Europe, there was a drastic decrease in the population caused by migration of the Proto-Persians to the south. Exactly in that period the presence of Zrubna population is defined to the east of the Caspian Sea and in the Upper Kuban Area. In that situation, migration to the Iranian Uplands could be made along the both shores of the Caspian Sea through the Kopet Dagh and Derbent Gates. In the conclusions to his research, the author schedules three main directions of the population's outflow from the steppe zone (the Trans-Caspian one, the Black Sea-Caspian one and the West-Black Sea one connected with the movement of 'the nations of the sea' (Otroschenko 2002, 22-27).

As far as the late Bronze Age, some researchers also emphasize movement (migration or invasion) of cultures in the meridian direction: from the Donets Area and the North-Western Black Sea Area. Moreover, the ore mining and smelting center ceased to exist in that very period (Kushtan 2013, 84). All this was primarily caused by the end of the climatic optimum that came at the end of the Sub-Boreal phase, causing a cold spell and a drought as a result of aridization of the climate, which led to the shift of the climatic zones (Gershkovich 1998, 81; Otroschenko 2002, 25; Romashko 1986, 132-134).

Migration transformation could not but affect the burial rite of $\mathrm{ZC}$ tribes inhabiting the Azov steppe, especially if the infiltration process was going on not instantly but within a certain period of time. Thus, at the final stage of ZC development in the North Azov Area, there was a deviation to the traditional burial rite, which inevitably led to loss of cultural identity; in terms of archeology, it led to disappearance of the culture itself. With disappearance of $\mathrm{ZC}$ mound rite in the region under 
research at the break of the $13^{\text {th }}-12^{\text {th }}$ c. B.C., ZC itself disappeared. Having appreciably decreased, the population of the Azov steppe did not completely disappear. Life was going on in particular settlements, though in a different cultural environment. Emergence of new cultural formations based on ZC genetic background (Boguslav/Bilozirsk and Otradne cultures) in the $13^{\text {th }}$ c. B.C. marked the final of $\mathrm{ZC}$ in the region under research.

\section{CONCLUSIONS}

In the North Azov Area, BMZC is presented as a well-molded one despite there is a small number of PZC sites as well. Being placed in mounds, the latter outnumber DDBC complexes of the early and the middle periods, occupying the stratigraphic position similar to late BCC complexes. This suggests the possibility of a certain synchronization of PZC sites with late BCC sites. There is also a well-known trend of decrease in Pokrovsk impulse in the western direction in the North Azov Area. However, this impulse from the Siverskyi Donets and from the Lower Don Area is considered as a catalyst that caused or accelerated transformation of the late-Babino substrate in BMZC. It is worth while taking into consideration that in the North Azov Area, together with the main block of DDBC sites, there is rather a small block of DPBC complexes. It is not worth while disregarding their participation in cultural genesis processes.

There was an overlapping of Pokrovsk features onto the late layer of BCC sites rather than a gradual change of cultures (Babino culture [DDBC III + DPBC] - PZC - BMZC). Since Pokrovsk features are rather implicit in ZC sites of the North Azov Area, they disappeared very quickly at the beginning of their early stage.
Due to the overall process of disintegration typical of the whole ZC Area accompanied by splitting into separate local groups, a number of post-ZC cultures were formed on a vast area of the late Bronze Age Steppe. In the North Azov Area, there was a deviation to the traditional burial rite at the final stage of ZC development. This led to loss of cultural identity; in terms of archeology, it led to disappearance of the culture itself. In the North Azov Area, with disappearance of the 'Zrubna' mound rite, ZC itself disappeared. Emergence of new cultural formations on the Zrubna genetic basis (Boguslav/Bilozirsk culture - in the western part of the region under research, Otradne culture - in its eastern part) marked the final of ZC in the North Azov Area.

ZC existence in the North Azov Area embraces the period of 1700-1200 B.C. The beginning of that period coincides with the end of BCC existence, whereas its end coincides with emergence of cultural formations of the late Bronze Age genetically connected with the ZC world. The end of the Bronze Age came with large-scale climatic changes as well as with changes in demography and migration. There was an apprecialble outflow of the population in the region under research. However, a part of the population that stayed in the steppe was most likely to participate in formation of Boguslav/Bilozirsk and Otradne cultures of the late Bronze Age.

The overall cultural dynamics of the late Bronze Age in the North Azov Area looks as follows: late Babino culture (DDBCK + DPBC) + PZC $\rightarrow$ BMZC $\rightarrow$ BCC i Otradne culture. The content of the initial phase of cultural genesis can be understood as transformation of the local Babino culture into BMZC with insignificant participation of PZC migrants. The disintegration processes of the late stage resulted in emergence of post-ZC cultural formations, such as BCC and Otrande culture.

\section{LITERATURE}

Berezanskaya 1982 -S. S. Berezanskaya: Severnaya Ukraina $v$ epohu bronzyi. North Ukraine in the epoch of the Bronze Age. Kyiv 1982.

Gavrilyuk 1982 - N. A. Gavrilyuk/Ya. P. Gershkovich: O pogrebeniyah finalnogo etapa bronzovogo i rannego zheleznogo vekov v basseyne r. Kalmius v Severnom Priazove. In: D. Ya. Telegin (red.): Materialyi po hronologii arheologicheskih pamyatnikov Ukrainyi. Kyiv 1982, 67-71.

Gershkovich 1998 - Ya. P. Gershkovich: Etnokulturnyie svyazi v epohu pozdney bronzyi v svete hronologicheskogo sootnosheniya pamyatnikov (Nizhnee Podneprove-Severo-vostochnoe Priazove-Podontsove). Arheologicheskiy almanakh 7, 1998, 61-92.
Gorbov 1995 - V. N. Gorbov: K probleme kulturnoj atributsii poseleniya na Belozerskom limane. In: Konvergentsiya $i$ divergentsiya $v$ razvitii kultur epokhi eneolita - bronzy Sredney i Vostochnoy Evropy II. Sankt-Peterburg, 1995, 52-72.

Gorbov 1996 - V. N. Gorbov: Rannesrubnyie poselencheskie kompleksyi Severo-Vostochnogo Priazovya. In: Dono-Donetskiy region v sisteme drevnostey epohi bronzyi Vostochnoevropeyskoy stepi i lesostepi. Voronezh 1996, 66-69.

Gorbov 1997 - V. N. Gorbov: Dve tradiczii primeneniya kamnya $\mathrm{v}$ domostroitelstve pozdnego bronzovogo veka. Arheologicheskiy almanakh 6, 1997, 145-162. 
Gorbov 2000 - V. N. Gorbov: Osobennosti domostroitelstva i planigrafii poseleniy v usloviyah stepnoy zonyi. In: Arheologiya i drevnyaya arhitektura Levoberezhnoy Ukrainyi i smezhnyih territoriy. Materialyi tematicheskoi nauchoi konferentsii. Donetsk 2000, 55-60.

Gorbov 2001a - V. N. Gorbov/A. N. Usachuk: Rannesrubno-mnogovalikovskiy gorizont na poselenii Razdolnoe v Priazove. Arheologicheskiy almanakh 10, 2001, 155-196.

Gorbov 2001b - V. N. Gorbov/A. N. Usachuk: O kontakte arhaicheskoy srubnoy i pozdnemnogovalikovoy kultur na Priazovskoy vozvyishennosti. In: Yu. I. Kolev (red.): Bronzovyiy vek Vostochnoy Evropyi. Samara 2001, 213-220.

Cherednichenko 1986 - N. N. Cherednichenko: Zrubnaia kultura (Zrubna culture). In: S. S. Berezanskaya/V. V. Otroschenko/N. N. Cherednichenko/I. N. Sharafutdynova (red.): Kulturyi epohi bronzyi na territorii Ukrainyi. Kyiv 1986, 44-82.

Kopylov 1994 - V. P. Kopylov: O transportny'kh sukhoputny'kh kommunikatsiyakh, prokhodyashhikh cherez Del'tu Dona v skifskoe vremya. In: Problemy skifo-sarmatskoj arheologii Severnogo Prichernomoriya. Zaporozhie, 1994, 89-91.

Kovaleva 1981 - I. F. Kovaleva: Sever Stepnogo Podneprovya $v$ srednem bronzovom veke. Dnepropetrovsk 1981.

Kushtan 2013 -D. P. Kushtan: Periodizatsiya i hronologiya pamyatnikov epohi pozdney bronzyi Tsentralnoy Ukrainyi. In: Problemyi periodizatsii $i$ hronologii $v$ arheologii epohi rannego metalla Vostochnoy Evropyi. Materialyi tematicheskoi nauchnoi konferentsii. Sankt Peterburg 2013, 80-85.

Lytvynenko 1993 - R. A. Lytvynenko: Kriterii vyideleniya pamyatnikov pokrovskogo tipa v basseyne Severskogo Dontsa. Novyie otkryitiya i metodologicheskie osnovyi arheologicheskoy hronologii. Arheolohicheskie izyskania 4, 1993, 86, 87.

Lytvynenko $1994 a-$ R. A. Lytvynenko: Srubnaya kultura basseyna Severskogo Dontsa (po materialam pogrebalnyih pamyatnikov). Dissertation thesis. Natsionalna akademiya nauk Ukrayiny. Instytut Arheolohii. Kyiv 1994.

Lytvynenko 1994b - R. A. Lytvynenko: O rannem gorizonte pogrebeniy zrubnoi kultury Severo-Vostochnogo Priazovya. In: Problemyi hronologii kultur eneolita bronzovogo veka Ukrainyi i yuga Vostochnoy Evropyi. Dnepropetrovsk 1994, 28-29.

Lytvynenko 1995 - R. A. Lytvynenko: Pamyatniki pokrovskogo tipa na Severskom Dontse. Arheologicheskie vesti 4, 1995, 73-82.

Lytoynenko 1999 - R. A. Lytvynenko: Periodizatsiya srubnyih mogilnikov Severo-Vostochnogo Priazovya. In: Drevnosti Severo-Vostochnogo Priazovya. Donetsk 1999, 4-23.

Lytvynenko 2009a - R. O. Lytvynenko: Geneza, rozvytok ta istorychna dolia kulturnoho kola Babyne (Genesis, development and historical fate of Babino cultural circle). In: S. M. Sanzharova (red.): Materialy i doslidzhennia $z$ arheolohii Skhidnoi Ukrainy. Vid neolitu do kimmeriitsiv 9. Luhansk 2009, 44-90.

Lytoynenko 2009b - R. O. Lytvynenko: Kulturne kolo Babyne (za materialamy pokhovalnykh pamiatok). Dissertation thesis. Natsionalna akademiya nauk Ukrayiny. Instytut Arheolohii. Kyiv 2009.

Lytoynenko 2014 - R. O. Lytvynenko: Skhidna peryferiia Dnipro-Prutskoi Babynskoi kultury (Eastern periphery of Dnieper-Prut Babino culture). In: R. O. Lytvynenko (red.): Starozhytnosti Pivnichnoho Azovia. Mariupol 2014, 27-41.

Otroschenko 1981 - V. V. Otroschenko: Srubnaya kultura Stepnogo Podneprovya (po materialam pogrebalnyih pamyatnikov). Dissertation thesis. Natsionalna akademiya nauk Ukrayiny. Instytut Arheolohii. Kyiv 1981.

Otroschenko 1995 - V. V. Otroschenko: Puti obmena - puti migratsiy. Epoha bronzyi Dono-Donetskogo regiona. Lugansk 1995, 18-19.

Otroschenko 2001 - V. V. Otroschenko: Problemy periodyzatsii kultur serednoi ta piznoi bronzy Pivdnia Skhidnoi Yevropy (kulturno-stratyhrafichni zistavlennia). Kyiv 2001.

Otroschenko 2002 - V. V. Otroschenko: Istoriia plemen zrubnoi kultury. Natsionalna akademiya nauk Ukrayiny. Instytut Arheolohii. Kyiv 2002.

Otroschenko 2003 - V. V. Otroschenko: K istorii plemen zrubnoi obschnosti. In: Arheologiya vostochnoevropeyskoy lesostepi 17. Dono-Donetskiy region v epohu bronzyi. Voronezh 2003, 68-96.

Otroschenko 2012 - V. V. Otroschenko: Povertaiuchys do temy ostannikh pokhovan zrubnoi spilnoty. Donetskyi arheolohichnyi zbirnyk 16, 2012, 246-250.

Otroschenko 2013 - V. V. Otroschenko: Kurhan 1 bilia s. Hnarovske v Nadporizhzhi. Donetskyi arheolohichnyi zbirnyk 17, 2013, 150-179.

Otroschenko/Shevchenko 1987 - V. V. Otroschenko/N. P. Shevchenko: O vostochnoy granitse i vostochnyih svyazyah plemen belozerskoy kulturyi. In: Mezhplemennyie svyazi epohi bronzyi na territorii Ukrayiny. Kyiv 1987, 131-145.

Podobed 2014 - V. A. Podobed/A. N. Usachuk/V. V. Tsimidanov: Pokhovannia bilozerskoho chasu iz Pivnichno-Skhidnoho Pryazovia. Arheolohichnyi studii 5, 2014, 93-103.

Podobed/Usachuk/Tsimidanov 2012 - V. A. Podobed/A. N. Usachuk/V. V. Tsimidanov: Nekotoryie diskussionnyie problemyi arheologii yuga Vostochnoy Evropyi finala bronzovogo. Donetskyi arheolohichnyi zbirnyk 16, 2012, 194-245.

Polidovich/Tsimidanov 1994 - Yu. B. Polidovich/V. V. Tsimidanov: O naibolee pozdnih pogrebeniyah srubnoy kulturyi. In: Problemyi hronologii kultur eneolita bronzovogo veka Ukrainyi i yuga Vostochnoy Evropyi. Dnepropetrovsk 1994, 44-46.

Potapov 1998 - V. V. Potapov: Pogrebeniya belozerskogo hronologicheskogo gorizonta v basseyne Nizhnego Dona i Severo-Vostochnom Priazove. In: E. V. Vdovchenkov (red.): Problemyi arheologii Yugo-Vostochnoy Evropyi. Rostov-na-Donu 1998, 61-63.

Potapov 2010a-V. V. Potapov: Nekotoryie diskussionnyie problemyi arheologii finalnoy bronzyi i nekotoryie diskussionnyie resheniya etih problem. Donetskiy arheologichniy zbirnyk 17, 2013, 225-270.

Potapov 2010 - V. V. Potapov: Pamyatniki finalnoy bronzyi Nizhnego Podonya. Dissertation thesis. Rossyiska akademia nauk. Instytut Arheolohii. Moskva 2010. 
Potapov 2013 - V. V. Potapov: Nekotorye diskussionnyie problemy arheologii finalnoj bronzy i nekotorye diskussionnye resheniya etikh problem. Donetskyi arheolohichnyi zbirnyk 17, 2013, 225-270.

Probyiholova 2012 - O. S. Probyiholova: K voprosu o pohrebenyiakh fynala epohy bronzy $\mathrm{v}$ basseine Severskoho Dontsa. Sivershchyna v istorii Ukrainy 5, 2012, 42-46.

Probyiholova 2017 - O. S. Probyiholova: Naselennia nyzhnoi techii Siverskoho Dontsia ta Donetskoho kriazhu u zakliuchnyi period doby piznoi bronzy. Dissertation thesis. Natsionalna akademiya nauk Ukrayiny. Instytut Arheolohii. Kyiv 2017.

Romashko 1986 - V. A. Romashko: Prirodno-klimaticheskie usloviya i hozyaystvennaya deyatelnost naseleniya pogranichya Stepi i Lesostepi Levoberezhnoy Ukrainyi na rubezhe II-I tyis. do n.e. Problemyi arheologii Podneprovya 3, 1986, 120-136.

Romashko 2013 - V. A. Romashko: Zaklyuchitelnyiy etap pozdnego bronzovogo veka Levoberezhnoy Ukrainyi (po materialam boguslavsko-belozerskoy kulturyi). Kyiv 2013.

Samar 1998 - V. A. Samar: Verhnyaya hronologicheskaya granitsa KMK i pokrovskaya kultura Severnogo Priazovya. In: Problemyi izucheniya katakombnoy kulturno-istoricheskoy obschnosti (KKIO) i kulturno-istoricheskoy obschnosti mnogovalikovoy keramiki (KIOMK). Zaporozhe 1998, 75-83.

Manuscript accepted 6. 1. 2020

Translated by Mykhailo Tarapatov

Súhrn preložila Viera Tejbusová

PhDr. Viacheslav Zabavin Mariupol State University Budivelnykiv Ave. 129a

UA - 87500 Mariupol zabavinmdu@gmail.com
Sanzharov 1993 - V. A. Sanzharov/R. A. Litvinenko: Nekotoryie aspektyi istoriko-kulturnoy situatsii v Donetskom Priazove vtoroy chetverti II tyis. do n.e. In: Donbass i Priazove: Problemyi sotsialnogo, natsionalnogo i duhovnogo razvitiya. Mariupol 1993, 24, 25.

Shaposhnikova 1970 - O. H. Shaposhnikova: Bahatosharove poselennia poblyzu s. Rozdolne na Kalmiusi. Arheolohiia 13, 1970, 142-151.

Shapovalov 1979 - T. A. Shapovalov: K voprosu o vzaimootnosheniyah plemen mnogovalikovoy, abashevskoy i zrubnoy kultur v basseyne Severskogo Dontsa. In: Problemyi epohi bronzyi yuga Vostochnoy Evropyi. Materialyi tematicheskoi nauchoi konferentsii. Donetsk 1979, 70-73.

Sharafutdynova 1991 - E. S. Sharafutdynova: Pamyatniki kontsa epohi pozdney bronzyi na Nizhnem Donu i stepnom Prikubane. Sovetskaya arheologiya 1, 1991, 184-196.

Sharafutdynova 1993 - E. S. Sharafutdynova: Pamyatniki pokrovskogo tipa v Nizhnem Podone (Pokrovsk-type sites in the Lower Don Area). Novyie otkryitiya i metodologicheskie osnovyi arheologicheskoy hronologii. Arheolohicheskie izyskania 4, 1993, 87-90.

Sharafutdynova 1995 - E. S. Sharafutdynova: Nachalnyiy etap epohi pozdney bronzyi v Nizhnem Podone i na Severskom Dontse. Donskie drevnosti 4, 1995, 93-116.

PhDr. Maksym Bulyk

Mariupol State University

Budivelnykiv Ave. 129a

UA - 87500 Mariupol

m.bulyk@mdu.in.ua 


\title{
Kultúrna genéza a záver zrubovej kultúry v oblasti severne od Azovského mora (mladšia doba bronzová)
}

\author{
Vjačeslav Zabavin - Maksym Bulyk
}

\section{SÚHRN}

Príspevok sa zaoberá genézou zrubovej kultúry v regióne severne od Azovského mora a jej výskytom v tejto oblasti a počiatočným štádiom jej vývoja. Autori prinášajú pohlad na dejiny vývoja bádania tejto problematiky a zaoberajú sa hlavnými pojmami genézy a vývoja zrubovej kultúry v skúmanej oblasti. Autori tiež identifikovali množstvo znakov v ríte a inventári, ktoré sú charakteristické pre počiatočné štádium pochovávania zrubovej kultúry v oblasti severne od Azovského mora s objektmi kultúry Pokrovsk. Práve tieto komplexy možno považovat' za najranejšie zo zrubovej kultúry v regióne, kde sa pochovávalo podla kultúrneho okruhu Babino.

Berúc do úvahy skúsenosti predchodcov a na základe vypracovaných kritérií pre polohy typu Pokrovsk (zrubová kultúra pokrovského typu) zo susedných regiónov (oblast' riek Severský Donec a dolný Don) sa autori pokúsili vytýčit a charakterizovat’ najstaršie polohy zrubovej kultúry v oblasti severne od Azovského mora. Vykonaná práca ukázala, že pre najstaršie azovské hroby sú typické aj významné pokrovské znaky - hroby v jamách, ktoré sú prekryté drevom, zriedkavejšie kameňom, mierne až stredne skrčená poloha a orientácia smerom k severnému sektoru. Čo sa týka keramiky, je tu množstvo keramických predmetov, ktoré sa vyznačujú archaickými znakmi odvodenými od pokrovskej tradície a bronzové nože s mierne naznačenými výstupkami označujúcimi kosoštvorcový prierez.

Na druhej strane môžeme predpokladat, že rítus a inventár najstarších azovských hrobov patriacich do zrubovej kultúry rovnako charakterizuje isté množstvo znakov odrážajúcich autochtónnu babinskú tradíciu (pozícia rúk, orientácia tela, relikty v materiálnom súbore, atd'). Pokial' ide o kultúru a históriu, príchod zrubovej kultúry do oblasti severne od Azovského mora súvisí s migráciou nositel'ov z polôh pokrovského typu do tohto regiónu z lesostepí Doneckej oblasti cez údolie rieky Severský Donec, ktorej sa aktívne zúčastnila aj autochtónna populácia kultúry Babino.

To všetko je mimoriadne dôležité pre pochopenie kultúrnych a migračných procesy, ako aj historických osudov nositelov zrubovej kultúry severne od Azovského mora, ktorí žili v mladšej dobe bronzovej. Autori považujú za vhodné zdôraznit” odlišnost' v "mechanizmoch“ kultúrneho vývoja zrubovej kultúry na rieke Severský Donec, v oblasti severného Azovského mora a horného Podnepria. Ak sa vezme do úvahy postupný úpadok po- krovského impulzu smerom na západ a fakt, že pamiatky pokrovskej zrubovej kultúry sa v oblastiach severne od Azovského mora a horného Podnepria v danom období nevyskytujú, potom stratigrafia mohylových hrobov dokazuje, že po hroboch kultúrneho okruhu Babino nasleduje raná zrubová kultúra Berežnovka-Majevka. V regióne riek Dneper a Don môžeme hovorit’ o istom oneskorení v procese nahrádzania kultúry Babino zrubovou kultúrou v porovnaní s oblastou Don - Donec.

Tento článok sa takisto zaoberá problematikou týkajúcou sa určenia hornej chronologickej hranice zrubovej kultúry na území lavobrežnej Ukrajiny, konkrétne hranice označujúcej zánik a transformáciu zrubovej kultúry na nové kultúrne formácie záverečnej fázy mladšej doby bronzovej.

Niektorí vedci zdôrazňujú pohyb (migráciu alebo inváziu) kultúr v mladšej dobe bronzovej smerom po poludníku - z oblasti rieky Donec a zo severozápadnej oblasti Čierneho mora. Do rovnakého obdobia sa datuje aj koniec doneckých baníckych a hutníckych centier. Tieto migračné procesy boli zrejme spôsobené koncom klimaticky optimálneho obdobia, ktorý prišiel na konci subboreálnej fázy a priniesol obdobie chladu a sucha, čo bolo dôsledkom aridizácie podnebia. To napokon spôsobilo posun prírodných aj klimatických pásiem.

Migračná transformácia nevyhnutne ovplyvnila aj pohrebný rítus kmeňov zrubovej kultúry, ktoré obývali azovské stepi, najmä ak bol infiltračný proces skôr trvalý, než momentálny. Na základe metodologického princípu možno predpokladat', že najdôležitejším znakom archeologickej kultúry je viac alebo menej štandardizovaný pohrebný rítus, ktorý nepodliehal v priebehu času žiadnym zmenám. Azovské hroby zo záverečnej fázy mladšej doby bronzovej predstavujú inú kultúru, ked’že mnohé z nich vykazujú rituálne znaky, ktoré neboli typické pre zrubovú kultúru.

V rozlahlej oblasti stepi sa v mladšej dobe bronzovej vyformovalo množstvo post-zrubových kultúr, čo bolo spôsobené všeobecným princípom rozpadu typickým pre celú oblast' zrubovej kultúry. Toto formovanie sprevádzal rozpad na samostatné miestne skupiny. Oblast' severne od Azovského mora sa odchýlila od tradičného pohrebného rítu v záverečnej fáze vývoja zrubovej kultúry. To spôsobilo stratu kultúrnej identity a čo sa týka archeológie, zánik samotnej kultúry. So zánikom "zrubového" mohylového rítu v regióne severne od Azovského mora zaniká aj zrubová kultúra ako taká. 
Výskyt nových kultúrnych formácií na genetickom základe zrubovej kultúry (kultúra Boguslav/Bilozirsk v západnej časti skúmaného regiónu a kultúry Otradne na východe) znamenal koniec zrubovej kultúry severne od Azovského mora.

Obdobie existencie zrubovej kultúry siaha od roku 1700 do roku 1200 pred. n. 1. Začiatok tohto obdobia sa zhoduje s koncom kultúrneho okruhu Babino, kým jeho koniec sa zhoduje so vznikom kultúrnych formácií mladšej doby bronzovej, ktorá bola geneticky spojená so svetom zrubovej kultúry. Doba bronzová sa skončila tak rozsiahlymi klimatickými a demografickými zmenami, ako aj migračnými transformáciami, ktoré tieto zmeny spôsobili. Nastal značný prílev obyvatelstva do daného regiónu, zatial čo čast' obyvatel'stva, ktorá zostala v stepi, pravdepodobne participovala na vzniku kultúr Boguslav/Bilozirsk a Otradne v mladšej dobe bronzovej. 